\title{
POLITICAL ROOTS OF RELIGIOUS EXCLUSION IN TURKEY
}

\author{
Türkay Salim Nefes ${ }^{1}$ \\ Department of Sociology and Brasenose College, University of Oxford
}

Do perceived political threats lead to religious exclusion? This study explores the political rationale of the exclusionary attitude towards non-Muslim minorities in Turkey. It relies on a qualitative content analysis of the discussions on the Armenian, Greek and Jewish foundations in the Turkish parliament in the 2000s. While doing so, the research brings together the academic literatures on the perception of religious minorities in Turkey with the group threat perspective. The findings show that the exclusionary statements about the nonMuslim minorities are often justified by suspecting them as potential plotters of the dismemberment of the country. The paper concludes that to achieve an inclusive political culture in Turkey, it is imperative to understand the perceived national security threats. It also underlines that parliamentary debates constitute an ideal resource for research, which deserves greater attention.

\section{Article History}

Received: 15 August 2017

Accepted: 18 September 2017

Keywords: Political Exclusion, Religious Minorities, Group Threat Theory, the Sevres Syndrome, Non-Muslim Communities in Turkey, Parliamentary Proceedings

Turkish national anthem, the Independence March, begins with an assurance that the nation will exist forever: 'Fear not! For the crimson banner that proudly ripples in this glorious dawn, shall not fade'. This apprehensive emphasis on the future existence is fathomable within the historical context: the Turkish Republic is a successor of the Ottoman Empire, which collapsed due to the wars against foreign powers and independence movements of its various minorities. This historical background generated an ontological insecurity in Turkish politics, about a threat of dismemberment, called the Sevres syndrome, which manifests itself with distrust to the Western powers and internal minorities (Göçek, 2011; Nefes, 2012). This study scrutinises the significance of the Sevres syndrome on the perception of non-Muslim minorities, namely Armenians, Jews and Greeks, in contemporary Turkish politics. It explores to what extent the ontological insecurities pave way to exclusionary politics about non-Muslims in Turkey. The paper proposes that the exclusionary attitude is largely a function of the perceived threats about the dismemberment of the country.

\footnotetext{
${ }^{1}$ CONTACT: Address: Camlik cd., Cigdem sk., Mutlu ap., No: 7/5, 34182, Bahcelievler, Istanbul, Turkey. E-mails: turkay.nefes@ sociology.ox.ac.uk ; thefes@gmail.com
} 
The focus of the analysis is on the discussions about the non-Muslim charity foundations in the Turkish parliamentary proceedings between 2002 and 2008. In particular, the debate concerning the property ownership rights of the non-Muslim foundations of Armenians, Greeks and Jews. It is an ideal case to understand the relationship between exclusionary attitude towards non-Muslims and the Sevres syndrome for three reasons. First, it concerns all major non-Muslim minorities in the country together and therefore presents an excellent opportunity to examine the political perception of these groups from a holistic perspective. Second, it is a very significant and persistent discussion in the 2000s that clearly reflects the political attitudes towards these minorities. Third, thematically, the debate is relevant to the ontological insecurities about dismemberment, as it prompts both exclusionary and inclusionary political views about the land ownership of the non-Muslim minorities.

In various ways, the research develops the relevant scholarships. To start with, it is one of the first studies that use the Turkish parliamentary proceedings, an ideal but underrated source of systematic data from mainstream politics, to explore the perception of the non-Muslim minorities. In so doing, it not only delineates the political rationale of the exclusion of the religious minorities in depth by a qualitative content analysis but also presents parliamentary records as an ideal source for political science. In addition, it provides a theoretically novel perspective by bringing together the threat perspective (e.g. Blumer, 1958) with the academic literature on the Turkish perception of non-Muslims (e.g. Bali, 1998, 2001). Third, it develops the group threat perspective by bringing evidence from an underexplored context, Turkish politics at macro-level. Furthermore, the study contributes to the academic literature on property restitution in the Council of Europe countries, a new and increasingly important field of study. The Turkish government lost court cases about property restitution at The European Court of Human Rights, such as the Loizidou vs. Turkey (Spyridakis, 2008). Below, the paper begins with a brief historical background of the non-Muslim minorities in Turkey and the laws about the property rights of the non-Muslim foundations. Subsequently, it delineates the relevant scholarships and the methods used. Last, the paper discusses the implications of the findings.

\section{Historical background of the non-Muslims in Turkey: from an imperial subject to a modern citizen}

To understand the non-Muslim communities' perception in the Turkish Republic, we should mention their position in the Ottoman Empire (1299-1923). Between the fifteenth and the nineteenth centuries, the prominent non-Muslim communities, namely the Greek-Orthodox, Armenian-Gregorian and Jewish communities, lived under the millet (meaning religious community in Turkish) system. These minorities had a freedom to manage their internal religious, educational, juridical and fiscal affairs (Barkey, 2008; Barkey and Gavrilis, 2016; Bedlek, 2016). They were organised around their religious authorities. For example, the Ecumenical Patriarch of Constantinople (Patrick) was the head of the Greek Orthodox community. While the millet system recognised the autonomy of the non-Muslim communities, they were in a subordinate position to the Ottoman ruler. They paid extra taxes and were not allowed to serve as state officers, unless they converted to Islam (Içduygu et al., 2008). The millet system gradually weakened during the collapse of the Ottoman Empire in 
the nineteenth and early twentieth centuries. The establishment of the Turkish Republic in 1923 meant the abolishment of the millet system.

Before going into the non-Muslim communities' transition from the Ottoman millet system to the modern citizenship in the Turkish Republic, we should briefly outline the negative impacts of the downfall of the empire on the perception of the religious minorities. This period saw ethnic minority independence movements and wars with foreign powers that costed a rapid and heavy land loss to the empire. In order to avoid the impending collapse, the Ottomans attempted to modernise. They sent students to Europe to learn the latest technologies and employed foreign experts to modernise their institutions. Political reforms also accompanied this process: the Tanzimat reforms gave more minority rights to all minorities in 1839. However, these were not enough to solve the weighty problems, and the coming collapse created a negative view of the minorities. It produced a suspicion about their loyalty to the empire, as many rebelled and established their independent states. This was manifest in the evolution of the ideological directions to save the empire, which quickly lost hope to include non-Muslims as citizens. Initially, the Ottomanism attempted and failed to unite all ethnic and religious subjects of the empire under the Ottoman identity. Subsequently, the non-Muslims were dropped of the imagined unity, as the Islamist ideology imagined a Muslim nation regardless of the ethnic differences, and Turkism aimed to create an Ottoman nation ruled by ethnic Turks. These alternating ideological attempts seem to show the beginnings of the exclusionary view about the non-Muslim communities in modern Turkey.

The collapse of the Ottoman Empire was complete at the end of the First World War. It was secured by the signature of the Sevres Treaty with the Allied Powers. The treaty was a heavy agreement for the Turkish side, which led them to wage the Turkish Independence War (1919-1923). Subsequently, they established the Turkish Republic after signing the Lausanne Peace Treaty in 1923. The Ottoman collapse period and the Sevres Treaty left a traumatic perception of the non-Muslim minorities among the Turkish political elite. They saw minorities as a potential fifth column, who could act in the interests of foreign powers once the opportunity arises. This suspicion about the conspiracies of external enemies and internal minorities to weaken and dismember the Turkish Republic is called the Sevres syndrome in the scholarship (Göçek, 2011).

Turkish political elite's wary view about the minorities was reflected in their approach to the Lausanne Peace Treaty. The agreement initially promised the continuity of the millet system and secured the autonomous rights of the non-Muslim communities (Bali, 1998). Given the Ottoman past, the Turkish state was not willing to give much autonomy and intended to create a homogenous society (Toktaş, 2005). Hence, they pressured the non-Muslim communities to renounce these rights of autonomy. First the Jewish community and then the Armenians and Greeks renounced them to avoid state hostility (Aviv, 2017). The Lausanne Treaty meant a transition of their legal status to modern citizenship. On the positive side, it promised them an equal position as the citizens of Turkey. On the negative side, they lost the autonomy that they enjoyed in the Ottoman period. In addition, the proposed equality in law did not match their de facto treatment (Nefes, 2015b). For example, although he Capital Levy of 1942 intended to tax the citizens who made fortunes from the wartime economy (Neyzi, 
2002), it was heavy-handed on non-Muslim minorities. They were forced to pay very high taxes, and the ones who could not afford them were sent to 'work camps' in Eastern Anatolia to labour in difficult conditions.

The legal changes about the property ownership rights of the minorities present an ideal case about the unmet promises of the modern Turkish citizenship of the non-Muslims. The Turkish state required the non-Muslim foundations to provide an inventory of their belongings in 1936. These foundations were allowed to buy and sell properties and accept donations until 1974, when the Turkish state declared the acquired property of the foundations after 1936 as illegal, because foreigners were not allowed to gain asset in Turkey (Varol, 2005). This led to returning of the foundations' properties, acquired after 1936, to their donors. Varol (2005) underlines that this meant their loss of property to the Treasury of the Turkish Republic, as not many of the original donors, who mostly had left the country, could have been found. Varol (2005) adds that this has had important economic repercussions for the foundations, as their primary source of income was coming from rents. The AKP government passed legal changes in 2003 that allowed the foundations to acquire properties and to demand their confiscated properties from the past. Nevertheless, the Turkish courts often did not grant the applications from the foundations, and the AKP government attempted to pass another law to ensure that they will be returned without seeking court permission. The President of the period, Ahmet Necdet Sezer returned the legal changes passed in the parliament in 2006, defending the decision in 1974. Finally, the succeeding president, $\mathrm{Mr}$ Abdullah Gül, approved the legal changes in 2011.

\section{Perceptions of threat and non-Muslim minorities}

One of the prominent lines of the academic literature on ethnic and religious prejudice is group threat theory. This perspective assumes that prejudice arises from dominant group members' perception of outgroups as a threat to their prerogatives (e.g. Blumer, 1958; Bobo, 1983, 1999; Olzak, 1992; Semyonov et al., 2006). The theoretical approach frames intergroup perceptions similar to a zero-sum game mentality, where a subordinate group's gain is perceived to be taking place at the expense of the dominant group. The central arguments of the group threat theory are as follows: (a) dominant group members see themselves entitled to certain rights and privileges; (b) any perception of threat to these prerogatives would incline members of the dominant group members towards negative prejudices about subordinate groups. In other words, group threat theory links social position to dominant group members' perception of others. Blumer (1958) argued that four types of feelings shape prejudiced attitude: (1) dominant group's superiority; (2) the essential difference of the subordinate groups; (3) dominant group's proprietary claim to certain areas of privilege and advantage; (4) fear about other groups' designs on their privileges. He prioritised the third feeling, as he saw prejudice as a defensive reaction. That is to say, prejudice is a protective device, historically and collectively developed to defend social positions (Blumer, 1958).

Using the group threat perspective, studies demonstrate that the negative perception of subordinate groups would increase with a growth of their population and worsening economic conditions in the developed world (e.g. Blalock, 1956; Fosset and Kiecolt, 1989; Schneider, 2008). These valuable researches tend to focus on public members' perception of 
threat in the developed world. This micro-level emphasis sets a limitation, because it does not adequately examine the macro-level historical and political influences on prejudice. Quillian (1995, 1996) underlined the importance of the historical and cultural components of the relationship between dominant societies and outgroups and admitted that precise measures of these factors are not available. The academic literature can benefit from studies on less developed countries and looking into macro-level factors of prejudice. Indeed, this study contributes to the group threat perspective by focusing on macro-level politics of an underexplored context, Turkey.

One of the most significant sources of the perceived threats in Turkish politics is the Sevres syndrome (Guida, 1998). Accordingly, it is not farfetched to argue that the Sevres syndrome would have implications on the apprehensive political perception of the ethnic/religious minorities. Indeed, Gol (2005) claims that the Turkish state's exclusionary practice towards the Armenian minority was because of its threat perception of the Armenian claims on the Turkish territory. In his analysis of the parliamentary debates about the Kurdish question in the 1990s, Loizides (2009) finds that the Sevres syndrome predominantly shaped most of the political parties' perspectives. Nefes $(2013,2015 \mathrm{a}, 2015 \mathrm{c})$ demonstrates that the anti-Semitic conspiratorial rhetoric among the public and political parties often underlined the perceived threat of dismemberment. This seems to resonate with the argument that Turkish nationalism sees Islam as the indispensable component of the Turkish identity and excludes the nonMuslims from the definition of the nation (Yildiz, 2001). One of the formulators of the Turkish state ideology, Ziya Gokalp, did not include non-Muslims in his definition of the new nation. Interpreting Emile Durkheim's sociological approach in the Turkish context, he explained that the origin of Turkish culture is rooted in Sunni Hanafi Islam. Moreover, the population exchange with Greece, which meant expelling 1.2 million Orthodox Christians to Greece and in return receiving four hundred thousand Muslims, exemplifies the nature of Turkish state nationalism and its preference for Muslim subjects. In parallel, various studies underline that Turkish-Jews are seen as a foreign group in Turkey (Bali 2001; Brink-Danan, 2012). All in all, the study brings together the literature on group threat and perception of minorities in Turkey and claims that the exclusionary attitude towards the non-Muslim minorities is a function of the perceived threats about the dismemberment of the country.

\section{Method}

This paper examines the Turkish parliamentary proceedings between 2002 and 2008 to understand the political roots of religious exclusion in Turkey. The proceedings are an ideal source, as they contain systematic and representative evidence with regards to the political parties' positions on the debates related to the minorities (Loizides, 2009). Moreover, they include the non-verbal reactions of the Turkish politicians, such as clapping or booing, which provide further depth to the analysis. Various studies already demonstrate excellent evidence on different aspects of mainstream Turkish politics through looking at the parliamentary proceedings (e.g. Doganay, 2007; Loizides 2009). This inquiry relies on a qualitative content analysis of the parliamentary proceedings. This unobtrusive, flexible and transparent method helps to afford an in-depth understanding of the text by enabling to consider both manifest and latent content (Cabrera and Reiner, 2016; Sandelowski 2000; Wolff 2007). Qualitative content analysis helps to interrogate the data be able to identify categories that highlight the 
key content (Drisko and Maschi, 2015: 88). Indeed, these are imperative requirements for the current study, as it focuses on the Turkish political jargon in the parliament, where politicians often use symbolic metaphors.

To do that, I reached the parliamentary proceedings at the digital archives of the Turkish Grand National Assembly (https://www.tbmm.gov.tr/develop/owa/td_v2.sorgu_ekrani). First, I searched the archive by using relevant keywords, such as Armenian, Jew and Greek. After an exploratory analysis of the debates on the non-Muslim minorities in the 1990s and 2000s, I found that the discussions on the land ownership rights were one of the most significant and foundational debates that often refers back the establishment of the Turkish Republic. Thus, I focused the main inquiry to the parliamentary debates on this topic in the 2000s.

\section{The debates and actors at the parliament}

This research brings together three parliamentary debates concerning the property rights of the non-Muslim Foundations in 2002, 2006 and 2008. The first was about a change in the law that removed the legal terms against the foundations' right to own property. This was suggested by the AKP government and the passed in the parliament. Subsequently, along with the legal changes that were brought by the European Union (EU) candidacy, the AKP government proposed further changes in the legal terms about the property rights of the foundations in 2006. This led to a longer debate but the changes were approved by the majority of the parliament. The third debate took place in 2008, as the President Sezer did not approve all the legal changes of the law that passed in 2006 and returned some of the clauses to be further discussed in the parliament.

As it can be seen in table 1 below, political parties from the right-wing to the left have contributed to the debate. Members of 10 political parties and an independent MP made 113 speeches on the issue. The political parties that contributed to the debate are as follows: the governing Justice and Development Party (AKP) and several opposition parties, namely The Motherland Party, (ANAP), Great Unity Party (BBP), Republican People's Party (CHP), Democratic Left Party (DSP), True Path Party (DYP), People's Democratic Party (HDP), Nationalist Action Party (MHP), Felicity Party (SP), and New Turkey Party (YTP). Overall, 41 speeches were in favour of the changes, while 69 contributions were against. In addition, three speeches on the topic did not address the discussions directly and therefore are excluded from the analysis. 
Table 1 Summary of the debate and the participants

\begin{tabular}{|l|l|l|l|l|}
\hline Year & Political party & Ideological position & Political position & Speech frequency \\
\hline \multirow{5}{*}{2002} & AKP & Centre-right & In favour & 1 \\
\cline { 2 - 5 } & ANAP & Centre-right & In favour & 1 \\
\cline { 2 - 5 } & DSP & Centre-left & In favour & 1 \\
\cline { 2 - 5 } & DYP & Centre-right & In favour & 1 \\
\cline { 2 - 5 } & MHP & Right (Nationalist) & Against & 2 \\
\cline { 2 - 5 } & SP & Right (Islamist) & In favour & 1 \\
\cline { 2 - 5 } & YTP & Centre-left & In favour & 1 \\
\hline \multirow{5}{*}{2006} & AKP & Centre-right & In favour & 8 \\
\cline { 2 - 5 } & ANAP & Centre-right & Against & 2 \\
\cline { 2 - 5 } & CHP & Centre-left & Against & 25 \\
\hline \multirow{5}{*}{2008} & AKP & Centre-right & In favour & 27 \\
\cline { 2 - 5 } & BBP & Right & Against & 1 \\
\cline { 2 - 5 } & DHP & Centre-left & Against & 19 \\
\cline { 2 - 5 } & HDP & Centre-left & Against & 1 \\
\cline { 2 - 5 } & MHP & Left (pro-Kurdish) & In favour & 4 \\
\cline { 2 - 5 } & Independent & Centre-left & Against & 19 \\
\hline
\end{tabular}

\section{Rationale in favour of the legal changes}

The political parties that welcomed the law changes are the AKP, HDP, SP, ANAP, DSP and YTP. The ANAP and DSP only supported the changes in the discussions in 2002 and then took an opposite direction in 2006 and 2008. Main rationales put forward to support the law can be listed as follows: (1) Equality of all citizens of Turkey; (2) Responding to the needs of (a) religious communities, (b) general society and (c) cultural heritage; (3) The changes will eventually benefit the Turkish citizens living abroad; (4) Turkey loses court cases in the European Court of Human Rights and pay fines with the existing practice.

To start with the first theme, all supporting political parties underlined that the non-Muslim minority members are also Turkish citizens, who should have the same property rights as the Muslim citizens. Left-wing HDP reminded about the equality principle among different groups in the country. Hasip Kaplan expressed that as follows: 'our constitution ensures equality before law regardless of the lingual, racial, ethnic, political, religious and philosophical differences... the Turkish Republic recognises law above everything. This is not a tribal/primitive state'. ${ }^{1}$ In parallel, centre-left political parties, DSP and YTP, underlined that providing equal rights to all citizens are a necessity of the modern times. Ahmet Tan (DSP) stated that '...the Turkish Republic is a country of law... These changes will remove the complications with regards to equality... They will help to reach the standards of the modern civilization'. ${ }^{2}$ The ANAP and AKP agreed with this view. Nejat Arseven (ANAP) explained that 'according to the law about foundations, they should have the right to establish foundations and to buy property' ${ }^{3}$ 
Second, the AKP, DTP and SP talked about religious, social and cultural benefits of the proposed legal changes. Cevat Ayhan (SP) claimed that the legal changes would serve the needs of the religious minorities and added that there should also be improvements for the Muslim community foundations: 'If there is a religious community, its needs have to be satisfied by the state'. ${ }^{4}$ Moreover, the AKP stated that the legal changes would benefit the society in general. Ali Yuksel Kavustu expressed this as follows: 'thanks to the new law, these foundations will be able to serve the Turkish society in an effective way'. ${ }^{5}$ In parallel, the DTP MP Akin Birdal pointed to the societal benefits by claiming that the law would bring an improvement in terms of human rights: 'As you know, human rights refer to freedoms regardless of national, political, ethnic and gender identities. This law will help to protect these human rights in the country'. ${ }^{6}$ Last, the AKP posited that the changes would be beneficial for preserving the cultural heritage of minorities in Turkey. Yasar Karayel highlighted that need in the following manner: 'Looking after our cultural heritage does not only mean being proud of the national soul and social institutions, but also taking care of it'. ${ }^{7}$

Third, the AKP and ANAP suggested that the new laws about the religious minorities would benefit the treatment of the Turkish citizens living outside Turkey. Dengir Mir Mehmet Firat (AKP) explained that as follows: '...we should be open to synagogues and churches. Otherwise, we endanger the minority rights of our four million people living abroad... The world is watching us'. ${ }^{8}$ In parallel, Nejat Arseven (ANAP) stated that with this law 'we will be able to protect and develop the Turkish foundations abroad'. ${ }^{9}$ Fourth, the AKP and DTP reminded that Turkey was losing court cases and pay fines in the European Human Rights Court because of the existing inequalities with regards to the foundations right to own property. Thus, the legal changes were indispensable to prevent these losses. Hayati Yazici (AKP) highlighted that the minority foundations sued Turkey in the European Court of Human Rights (ECHR) and won their cases, which forced Turkey to pay compensation. ${ }^{10}$ Hasip Kaplan (HDP) also reminded about these losses and how they pointed to the need of legal changes. ${ }^{11}$ Indeed, as Celik (2005) illustrated in detail on the Kurdish question in Turkey, the recognition of the power of the ECHR put pressures on the Turkish state for a more positive approach to human rights policies with regards to minorities.

\section{Rationale against the legal changes and the response}

The CHP, MHP, BBP, DYP, ANAP (in 2006), DSP (in 2008) MPs and the independent MP Kamer Genc spoke against the legal changes. All of the opposition delineated the proposed legal changes as a grave mistake that carve up of the Turkish Republic. The MHP provided the most fervent speeches. Hasan Calis (MHP) claimed that 'Armenian and Greek lobbies demand more rights by hiding behind the EU... you can see that they will not stop until they cleansing the Anatolia from Turks'. ${ }^{2}$ The opposing MPs supported their cases by emphasizing legal, political and security reasons: (1) dismemberment threat, (2) political futility of the changes, and (3) legal complications of the proposed laws.

To begin with the most significant theme, all opposing political parties described the laws as an existential threat imposed by foreign powers, reminiscent of the Sevres syndrome. First, MHP, ANAP and CHP drew analogies between the legal changes and the collapse of the Ottoman Empire. Mehmet Sandir (MHP) stated that 'like the legal processes during the 
collapse of the Ottoman Empire, these laws stab Turkey in the back... ${ }^{13}$ Ibrahim Ozdogan (ANAP) added that the Western powers try to reintroduce the Sevres Treaty that ensured the end of Ottoman Empire. ${ }^{14}$ Second, the MPs explained that this foreign conspiracy would take place by giving excessive rights to 'foreigners'. Mehmet Vedat Yucesan (CHP) argued that 'these new laws will provide foreigners a right to establish foundations and own property... these pose a very important threat with regards to national unity and security'. ${ }^{15}$ Osman Ertugrul (MHP) warned about the potential missionary threat: 'Non-Muslim foundations will become ideal places for missionaries to convert their target populations. The proposed legal changes will help them to achieve their goals'. ${ }^{16}$ In line with that, Muhsin Yazicioglu (BBP) accused that the Soros Foundation would find a great opportunity to conspire against Turkey. ${ }^{17}$ Last, the DSP framed these legal changes as a grave economic threat. Harun Ozturk declared that ' $\ldots$ these threaten our economic independence and therefore the political independence of the Turkish Republic' ${ }^{18}$

Another argument was that the proposed changes were politically ineffective. This was expressed in two main ways with regards to: (a) foreign relations and (b) the corruption. First, The CHP, MHP and the independent MP Kamer Genc contended that these laws were products of the AKP government's inefficient foreign policy. They claimed that these changes were unjustly imposed by the EU. Hasan Calis (MHP) stated that 'Greece, Cyprus and Romania have become EU members. Did they face any requirements to change their laws on religious foundations? No!' ${ }^{19}$ Accordingly, they portrayed the AKP government's endeavour as a wrong political strategy in the negotiations with the EU. Tuncay Ercenk (CHP) summarised this as follows: 'We pass all the laws and sign all the protocols imposed by the EU without hesitation. We passively accept the United Nation's Annan plan for Cyprus... However, we do not have any progress in our EU membership candidate status. This submissive policy is not how we can become an EU country' ${ }^{20}$ In parallel, Genc (Independent) suggested that these laws should be enacted once Turkey becomes an EU member. Second, centre-left CHP and DSP proposed that the new changes would lead to political corruption. Harun Ozturk (DSP) stated that 'with these legal changes, the AKP government will only cooperate with the partisan foundations in line with their political agenda'. ${ }^{21}$

Third main argument the opposition underscored that the proposed changes contradict the existing laws and the Lausanne Treaty. To start with the latter, the CHP, DSP, DYP and MHP representatives all underlined that the proposed laws contradicted the main principles of the Lausanne Treaty, which set the legal foundations of the Turkish Republic. Sevgi Esen (DYP) stated that 'the fourth clause of the new law contrasts the principles of the Lausanne Treaty. These changes have to be amended'. ${ }^{22}$ In addition, Halil Unlutepe (CHP) proposed that 'the Lausanne Treat secures the existence of the Turkish Republic. The new laws will leave the treaty dysfunctional... The new law looks a lot like the Sevres Treaty'. ${ }^{23}$ Second, the MPs from the CHP, DYP and MHP also pointed that the law was not in line with the Turkish Constitution. Orhan Eraslan (CHP) explained how the law contradict the constitution:

The Lausanne Treaty is approved by the Turkish Constitution (clause no. 90) and therefore contradicting the treaty is breaching the constitution. In addition, the civil law (101/4) states that "no one can establish a foundation to support a religious 
community, ethnicity or a sect', and therefore, when you breach this, you break the constitution's clause number $10{ }^{24}$

Last, the AKP responded to all these criticisms by reassuring that the changes did not constitute a dismemberment threat in four ways: (a) the state will be closely inspecting the actions of these foundations; (b) we have enough trust in the strength of the Turkish Republic to believe that providing these freedoms will not diminish its power; (c) the non-Muslim foundations will not be allowed to engage in international activities; and (d) the legal changes are in line with the Turkish Constitution and the Lausanne Treaty. Moreover, the AKP members condemned the opponents by claiming that they criticised because of their political interests not for the welfare of the country. It should not go without saying that even though most of these claims were from the AKP other MPs, such as Hasip Kaplan (DTP) and Nejat Arseven (ANAP), were also critical of the opponents' depiction of the legal changes as an existential threat to Turkey.

\section{Discussion and conclusion}

The parliamentary debate about the property ownership rights of the non-Muslim minority foundations in Turkey lucidly shows that the exclusionary perspective about the Armenian, Greek and Jewish communities tends to be justified through existential threats about the dismemberment of the country, the Sevres syndrome. The findings point to three main reasons that opponents posited to avoid modernizing the property ownership rights of the non-Muslim foundations: (a) the dismemberment threat; (b) political futility, (c) legal complications. All these themes involve a sense of existential threat. The first and the most significant one is a direct expression of viewing religious minorities as a potential ally of foreign conspiracies that aim to dismember the country. In parallel, the other themes build on the logic that perceives providing rights to minorities as a potential security threat. The political futility reason presents the proposed legal changes as losing grounds and possibly land to the European Union. Third, the legal complications argument portrayed the proposed laws contradictory to the legal foundations of the Turkish Republic by claiming that they are incongruous with the constitution and the Lausanne Treaty. All in all, this paper reveals that to achieve an inclusive political culture in Turkey, not only democratic reforms are needed but also existential threats should be resolved.

This conclusion has important outcomes for the relevant scholarships. First and on a global scale, the paper affords supporting evidence to the group threat perspective (Blumer, 1958; Bobo, 1999; Olzak, 1992) by showing how they are used to justify exclusionary policies with regards to religious minorities. In so doing, it develops the threat theory by focusing on an underexplored context, Turkish politics, and by bringing evidence from macro-level politics, while the academic literature tends to focus on micro-level perception of threat by individuals. Second, the research contributes to the scholarship on Turkish politics by focusing on all non-Muslim religious minorities together. It underlines with evidence that historically formed existential threats are an important component justifying exclusionary politics towards the religious minorities in the country. This perspective can help to explain the general public perception of the non-Muslim minorities as outsiders (Nefes, 2015b). For example, the Turkish ultranationalist group called the Alperen Hearths protested Israel's 
restrictions on the access to the Al-Aqsa compound in 2017 in front of the main synagogues in Istanbul (Hurriyet Daily News, 2017). Choosing the worship places of Turkish Jews instead of the Israeli Embassy clearly presents how they view both as the same, and see Turkish Jews as foreigners. Last but not the least, the study clearly corroborates that parliamentary debates constitute an ideal and easily accessible source for research, which merit more attention from mainstream political science.

The paper examines macro-level politics in Turkey. The scholarship could go beyond this analysis by exploring the validity of its conclusions among the general public. It could explore relevant online conversations and public opinion polls. Expanding on these areas would give a more comprehensive picture about the perception of religious minorities at both macro and micro levels in Turkey. Given that religious hostility decides the fate of the Middle East, it is vital and urgent to explore the causes of the hostile politics towards religious minorities in Turkey. Moreover, future research could look into the relevance of the findings in different contexts by systematically analysing the parliamentary proceedings of other countries. A comparison with Greece could look into the mention of the word Turk in the parliament and contribute to few comparative researches in the scholarship (e.g. Loizides, 2015). Widespread digitization of the parliamentary proceedings in different countries enables such a task at very low costs. This would help us to understand and respond to the political roots and impacts of ethnic and religious exclusion from an international perspective. Lastly, the analysis could go beyond Turkey by focusing on other Council of Europe countries with regards to the European Court of Human Rights' (ECHR) significant decisions on religious freedom.

\section{Notes}

${ }^{1}$ See TBMM Tutanak Dergisi, 30 January 2008, p. 334.

${ }^{2}$ See TBMM Tutanak Dergisi, 02 August 2002, p. 78

${ }^{3}$ See TBMM Tutanak Dergisi, 02 August 2002, p. 84

${ }^{4}$ See TBMM Tutanak Dergisi, 02 August 2002, p. 73

${ }^{5}$ See TBMM Tutanak Dergisi, 08 November 2006, p. 691

${ }^{6}$ See TBMM Tutanak Dergisi, 20 February 2008, p. 32.

${ }^{7}$ See TBMM Tutanak Dergisi, 30 January 2008, p. 343.

${ }^{8}$ See TBMM Tutanak Dergisi, 02 August 2002, p. 75.

${ }^{9}$ See TBMM Tutanak Dergisi, 02 August 2002, p. 84

${ }^{10}$ See TBMM Tutanak Dergisi, 14 February 2008, p. 526

${ }^{11}$ See TBMM Tutanak Dergisi, 30 January 2008, p. 370

${ }^{12}$ See TBMM Tutanak Dergisi, 14 February 2008, p. 539

${ }^{13}$ See TBMM Tutanak Dergisi, 20 February 2008, p. 59

${ }^{14}$ See TBMM Tutanak Dergisi, 09 November 2006, p. 870

${ }^{15}$ See TBMM Tutanak Dergisi, 08 November 2006, p. 680

${ }^{16}$ See TBMM Tutanak Dergisi, 14 February 2008, p. 548

${ }^{17}$ See TBMM Tutanak Dergisi, 14 February 2008, p. 535

${ }^{18}$ See TBMM Tutanak Dergisi, 14 February 2008, p. 569

${ }^{19}$ See TBMM Tutanak Dergisi, 14 February 2008, p. 538 
${ }^{20}$ See TBMM Tutanak Dergisi, 09 November 2006, p. 828

${ }^{21}$ See TBMM Tutanak Dergisi, 14 February 2008, p. 569

${ }^{22}$ See TBMM Tutanak Dergisi, 02 August 2002, p. 82

${ }^{23}$ See TBMM Tutanak Dergisi, 29 February 2008, p. 163

${ }^{24}$ See TBMM Tutanak Dergisi, 09 November 2006, p. 820

\section{References}

Aviv, E. (2017) Antisemitism and Anti-Zionism in Turkey: from Ottoman Rule to AKP, London, Routledge.

Bali, R. (1998) ‘Cumhuriyet Döneminde Azınlıklar Politikası’, Birikim, 9, 80-90.

Bali, R. (2001) Musa'nin Evlatlari Cumhuriyet'in Vatandaslari, Istanbul, Iletisim Yayinlari.

Barkey, K. (2008) Empire of Difference: The Ottomans in Comparative Perspective, New York, Cambridge University Press.

Barkey, K. and Gavrilis, G. (2016) 'The Ottoman Millet system: Non-territorial Autonomy and its Contemporary Legacy', Ethnopolitics, 15, 24-42.

Bedlek, E. Y. (2016) Imagined Communities in Greece and Turkey: Trauma and the Population Exchanges under Atatürk, New York, I.B. Tauris.

Blalock, M. (1956) 'Economic Discrimination and Negro Increase', American Sociological Review, 21, 584-588.

Blumer, H. (1958) 'Race Prejudice as a Sense of Group Position', The Pacific Sociological Review, 1, 3-7.

Bobo, L. (1983) 'Whites' Opposition to Busing: Symbolic Racism or Realistic Group Conflict?' Journal of Personality and Social Psychology, 45, 1196-1210.

Bobo, L. (1999) 'Prejudice as Group Position', Journal of Social Issues, 55, 445-472.

Brink-Danan, M. (2012) Jewish Life in 21 $1^{\text {st }}$-Century Turkey: The Other Side of Tolerance, Bloomington, Indianapolis, Indiana University Press.

Cabrera, L.Y. and Reiner, P. B. (2016) 'A Novel Sequential Mixed-method Technique for Contrastive Analysis of Unscripted Qualitative Data: Contrastive Quantitized Content Analysis', Sociological Methods \& Research, 1-17. DOI: 10.1177/0049124116661575

Celik, A. B. (2005) 'Transnationalization of Human Rights Norms and Its Impact on Internally Displaced Kurds', Human Rights Quarterly, 27, 969-997. 
Doganay, U. (2007) 'The Turkish Parliament on Democracy', Parliamentary Affairs, 60, 388-408.

Drisko, J. and Maschi, T. (2015) Content Analysis, New York, Oxford University Press.

Fossett, M. and Kiecolt, K. (1989) 'The Relative Size of Minority Populations and White Racial Attitudes', Social Science Quarterly, 70, 820-835.

Göçek, M. (2011) The Transformation of Turkey: Redefining State and Society from the Ottoman Empire to the Modern Era, London, I. B. Tauris.

Gol, A. (2005) 'Imagining the Turkish Nation through 'Othering' Armenians', Nations and Nationalism, 11, 121-139.

Guida, M. (2008) “'The Sèvres Syndrome' and 'Komplo' Theories in the Islamist and Secular Press', Turkish Studies, 9, 37-52.

Hurriyet Daily News (2017) 'Turkish Ultranationalist Group Stones Istanbul Synagogue during Protest against Al-Aqsa Restrictions', accessed at http://www.hurriyetdailynews.com/turkish-ultranationalist-group-stones-istanbul-synagogueduring-protest-against-al-aqsa-restrictions. aspx?PageID=238\&NID=115780\&NewsCatID=341 on 05 August 2017

Içduygu, A., Toktaş, Ş. and Soner, B. (2008) 'The Politics of Population in a Nation-building Process: Emigration of Non-Muslims from Turkey', Ethnic and Racial Studies, 31, 358-389.

Loizides, N. (2009) 'Elite Framing and Conflict Transformation in Turkey', Parliamentary Affairs, 62, 278-297.

Loizides, N. (2015) The Politics of Majority Nationalism: Framing Peace, Stalemates, and Crises, Stanford, Stanford University Press.

Nefes, T. S. (2012) 'The History of the Social Constructions of Dönmes (Converts)', Journal of Historical Sociology, 25, 413-439.

Nefes, T. S. (2013) 'Political Parties' Perceptions and Uses of Anti-Semitic Conspiracy Theories in Turkey', The Sociological Review, 61, 247-264.

Nefes, T. S. (2015a) 'Scrutinizing Impacts of Conspiracy Theories on Readers' Political Views: A Rational Choice Perspective on Anti-Semitic rhetoric in Turkey', British Journal of Sociology, 66, 557-575.

Nefes, T. S. (2015b) Online Anti-Semitism in Turkey, New York, Palgrave Macmillan.

Nefes, T. S. (2015c) 'Understanding the Anti-Semitic Rhetoric in Turkey through the Sevres Syndrome', Turkish Studies, 16, 572-587. 
Neyzi, L. (2002) 'Remembering to Forget: Sabbateanism, National Identity and Subjectivity in Turkey', Comparative Studies in Society and History, 44, 137-158.

Olzak, S. (1992) The Dynamics of Competition and Conflict, Stanford, California, Stanford University Press.

Quillian, L. (1995) 'Prejudice as a Response to Perceived Group Threat: Population Composition and Anti-immigrant and Racial Prejudice in Europe', American Sociological Review, 60, 586-611.

Quillian, L. (1996) 'Group Threat and Regional Change in Attitudes toward AfricanAmericans', American Journal of Sociology, 102, 816-860.

Schneider, S. L. (2008) 'Anti-immigrant Attitudes in Europe: Outgroup Size and Perceived Ethnic Threat', European Sociological Review, 24, 53-67.

Sandelowski, M. (2000) 'Focus on Research Methods-Whatever Happened to Qualitative Description?' Research in Nursing and Health, 23, 334-340.

Semyonov, M., Raijman, R. and Gorodzeisky, A. (2006) 'The Rise of Anti-foreigner Sentiment in European Societies, 1988-2000', American Sociological Review, 71, 426-449.

Spyridakis, V. S. (2008) 'Loizidou v. Turkey and the Future of Property Compensation for Refugees in Cyprus and Beyond', Journal of Modern Hellenism, 25-26, 129-156.

Toktaş, Ş. (2005) 'Citizenship and Minorities: A Historical Overview of Turkey's Jewish Minority’, Journal of Historical Sociology, 18, 394-429.

Varol, F. 2015. 'Religious Freedom as a Practice of the Nation: Religious Minorities, Islamic Revival, and the Emergence of Defensive Inclusion in Turkey', Dissertation, United States.

Wolff K. (2007) 'Content Analysis'. In Ritzer, G. (ed.) The Blackwell Encyclopedia of Sociology, Malden, MA, Oxford, Blackwell Publishers, pp. 776-779.

Yildiz, A. (2001) 'Ne Mutlu Turkum Diyebilene': Turk Ulusal Kimliginin Etno-Sekuler Sinirlari (1919-1938), Istanbul, Iletisim Yayinlari. 